\title{
A PROBLEM IN THE RECEPTION OF THE COMMON LAW IN THE COLONIAL PERIOD
}

\author{
George L. Haskins $\dagger$
}

The problem of the sources of the law in the American colonies has continued to attract the attention of scholars because its solution is pertinent to an understanding of the early history and social organization of the colonists. Important as a chapter in American legal history, the background of colonial law is likewise significant from a sociological point of view as a study in survival and adaptation of patterns of thought and habits of life. Historians have pointed out that the colonists drew extensively upon their English experience in their political institutions, in their religious ideas, even in their methods of farming, patterning their ways of thinking and of acting upon what had been familiar to them at home. In the law, too, it is beginning to be seen that the settlers availed themselves of their cultural heritage, bringing with them the knowledge or recollection of English law which they shaped to meet the needs of a new civilization.

If the process of transplantation, adaptation and innovation is to be described with accuracy, it is essential that the legal systems of the colonies be studied independently of one another. The background of the settlers differed widely from colony to colony, as did the social and economic conditions which affected the growth of the law; consequently, statements which are true for one colony are very often untrue for another. Accordingly, before a complete exposition of the sources and development of the law can be made, detailed accounts of the legal system in each are necessary in order to find the threads which will guide a sure path across the precarious territory of generalization. Such accounts have not, in general, been forthcoming, ${ }^{1}$ but it is nevertheless possible to make some advance by means of studies of particular branches of the law in particular colonies. The present study is concerned with aspects of the law of dower in seventeenth-century Massachusetts; its purpose is to suggest the sources of

$\dagger$ A. B., 1935, LL. B., 1942, Harvard University. Member of the Massachusetts Bar. Associate Professor of Law, University of Pennsylvania. Author, THE GrowTH of English Representative Governnant (1948); The Statute of York (1935); various articles in legal periodicals.

1. See, however, the excellent summary by Professor Zechariah Chafee in the first volume of RECORDS OF THE SufFolk COUNTY Court 1671-1680 (hereafter cited as SUFFolk County Records) in 29, 30 Publications of the Colonial Soctert of MassaCHUSETTS xvii to xciv (1933). 
that law and to show how it was shaped to meet the needs of the colonists.

Especial interest attaches to the origins and growth of the law in Massachusetts Bay both because of the availability of published records and because of the early development of an indigenous legal system in that colony. At one time that development was not well understood, and it was possible for writers to say that the seventeenth century was "a period of rude, untechnical popular law" 2 and that "the Scriptures were an infallible guide for both judge and legislator." 3 Close study of the records has resulted in the abandonment of that view, and it has become apparent that within fifty years of the settlement of the colony its courts were concerning themselves with difficult and complex questions of law to a degree which belies the assertion that during the seventeenth century Massachusetts possessed "a layman law, a popular, equitable system." " To say that the law was technical or complex is not, however, to say that by the third quarter of the seventeenth century the common law of England had been transplanted to New England shores. On the contrary, much of the law in early Massachusetts was noticeably different from the common law of England, despite the injunction of the colony charter that no laws should be made contrary to the laws of England. ${ }^{6}$

Such departures from common law rules have attracted the attention of scholars interested in the processes of legal development. Some years ago Professor Goebel suggested that those departures were comprehensible if the background of the settlers were kept in mind. ${ }^{7}$ His thesis, which grew out of an examination of the records of Plymouth Colony, was that the first settlers were recruited largely from the country districts in England from a class of society more familiar with the law and procedure in the local courts of the borough and the manor than with the common law which was administered in the king's courts, and that they brought with them many of the local customs which they had known at home. In the seventeenth century in England the common law had not acquired complete ascendancy over the local courts which administered a customary law. Those courts

2. Reinsch, The English Common Law in the Early American Colonies in 1 Select Essays in Anglo-American Legai History 367, 370 (1907).

3. Hilkey, Legal Development in Colonial Massachusetts in 37 Columaria Studies IN History, Economics and Public LAw 68 (1910).

4. Reinsch, supra note 2, at 385 .

5. See discussion in Morris, Massachusetts and the Common Law: The Declaration of.1646, 31 Axr. Hist. REv. 433 (1926).

6. 3 Thorpe, Federal and State Constitutions 1849 (1909).

7. Goebel, King's Lare and Local Custom in Seventeenth Century New England, 31 CoL. L. REv. 416 (1931). 
loomed large in the eyes of the average Englishman, for it was to them that he would turn to replevy a cow or collect a bill. By way of proof of his thesis Professor Goebel pointed to some remarkable parallels between the laws of Plymouth and the local customs prevailing in those districts of England from which the settlers had come. Subsequent examination of the records of the colony of Massachusetts Bay provided support for his thesis with respect to the sources of the law in that colony, where the influence of borough and manorial customs appears almost as prominent as at Plymouth. ${ }^{8}$

The law administered in the English local courts does not account for all sources of the law in seventeenth-century Massachusetts. In developing their law the colonists appear to have drawn also upon the Mosaic code ${ }^{9}$ and perhaps even upon Dutch law. ${ }^{10}$ Other portions, however, seem to have been direct adoptions of English common law rules. Although it has been urged that the common law remained an alien system until the mid-eighteenth century, when it was received into Massachusetts by trained lawyers and judges, ${ }^{11}$ the publication of the Laws and Liberties of 1648 has made it plain that the settlers had a certain familiarity with the common law and drew upon their knowledge of it in framing their code of laws. ${ }^{12}$ An illustration of their familiarity with the common law can be seen in the colonial law of dower.

Since the days of the Norman kings, English law had assured to a wife surviving her husband certain rights in his property after his death. Those rights had varied both in character and in extent, but typically they were rights in land. ${ }^{13}$ Until relatively modern times, land has been the chief form of wealth, so that the practise of allowing the widow a share in her deceased husband's lands afforded her the protection and means of livelihood which she required after his death. The rule early became established in the courts of common law that a widow should receive after the death of her husband an estate for her life in one-third of all the lands of which he had been seised during the marriage and to which issue of the marriage might by a pos-

8. Haskins, The Beginnings of the Recording System in Massachusetts, 21 B. U. L. Rev. 281 (1941); Haskins, The Beginnings of Partible Inheritance in the American Colonies, 51 Yale L. J. 1280 (1942).

9. Haskins, Partible Inheritance, supra note 8, at 1309-1311.

10. Haskins, Recording System, supra note 8, at 289-291; Haskins, Partible In heritance, supra note 8 , at 1301-1302.

11. Hilkey, supra note 3, at 5, 66 et seq., 144 ; Reinsch, supra note 2, at 367 et seq.

12. LAws AND LiberTIEs of Mass. (1929). See the detailed discussion of these laws by Wolford, The Laws and Liberties of 1648, 28 B. U. L. REv. 426 (1948).

13. For the early history of dower, see Haskins, The Development of Common Law Dower, 62 Harv. L. REv. 42 (1948). 
sibility succeed. ${ }^{14}$ That interest was known as dower. Dower rights attached upon marriage, unless the husband had made an adequate settlement on his bride beforehand, ${ }^{15}$ but she could not otherwise be deprived of her rights by will ${ }^{16}$ or by any other act of the husband alone during the marriage. She was entitled to dower in addition to what land or other property he might leave her by will ${ }^{17}$ or to what personal property she might be entitled if he died intestate. She might release her rights of her own volition, and she could be barred from them if she deserted her husband ${ }^{18}$ or if he divorced her for her adultery. ${ }^{19}$ After the death of her husband the widow's inchoate right became consummate, and she was entitled to have her third or thirds assigned to her by the husband's heir or other tenant of the land. ${ }^{20}$ If no assignment were made, she was entitled to a writ of dower to realize her rights. ${ }^{21}$

In addition to dower, local custom and the practise of the ecclesiastical courts which administered the personal estates of decedents generally gave the widow a share of his personal effects, if he died intestate. ${ }^{22}$ Of that portion her husband could not in early days deprive her by will, ${ }^{23}$. but after the fourteenth century, except by local custom, ${ }^{24}$ he acquired complete freedom of testation and might deprive her by will of any share in his personal effects. ${ }^{25}$

14. Co. LITT. $* 30$ b. "Tenant in dower is, where a man is seised of certeine lands or tenements in fee simple, fee taile generall, or as heire in speciall taile, and taketh a wife, and dieth, the wife after the decease of her husband shall be endowed of the third part of such lands and tenements as were her husband's at any time during the coverture, to have and to hold to the same wife in severalty by metes and bounds for terme of her life.

For purposes of this paper no discussion is necessary of dower ad ostitm ecclesiae, ex assensu patris, and de la pluis beale. See Haskins, supra note 13.

15. After the Statute of Uses, 1536, $27 \mathrm{HEN}$. VIII, c. 10, an ante-nuptial settlement in the form of a jointure, if properly executed, would bar dower. Co. LITT. *36 b. For details, see Scribner, A Treatise on the LAW of Dower, c. XV (1867).

16. Devises were not permitted at common law until the enactment of the Statute of Wills, 150,32 HeN. VIII, c. 1. Certain interests in land, such as leasehold, and land held by burgage tenure, were excepted from the common law rule. See 2 PoLlock \& MaItland, A History of ENglish Law Before tee Time of Edward I 115, 329-331 ( 2 d ed. 1911).

17. Co. LitT. $* 36$ b.

18. Id. at $* 32$ a; Coweld, The Interpreter $s$. $v$. "Dower" (1607).

19. 1 Rolle, Abridgment 681 (1668).

20. Co. Litr. $* 34$ b, $* 35$ a.

21. Id. at $* 35$ a.

22. 2 Pollock \& Maitland, op. cit. supra note 16, at 349-351.

23. If a man were survived by a widow and children, his testament was effective only as to one-third of his personal property; if he were survived by a widow or children, but not by both, it was effective as to one-half. GLANville, DE LEGIBUS, VII, 5. The shares of the widow and children could be enforced by the writ de rationabile parte bonorum. Id. at 7.

24. For example, in York and London, where the system of forced shares was not abolished until 4, 5 WM. \& MARY, c. 2 (1692), and 11 GEO. I, c. 18 (1724), respectively.

25. 3 Holdsworth, A History of English Law 552 (1935). 
Such, generally, were the rights of a widow in the property of her deceased husband in seventeenth-century England. As to her rights in the colony of Massachusetts Bay, little is known before 1641. In that year it was provided in the Body of Liberties that

If any man at his death shall not leave his wife a competent portion of his estaite, upon just complaint made to the Generall Court she shall be relieved. ${ }^{26}$

Evidently that provision was thought inadequate, for in 1647 the following enactment, prefaced by an italicized preamble, was made by the General Court:

Forasmuch as no provision hath yet been made for any certein maintainance for $W$ ives after the death of their Husbands, be it ordered and enacted by this present Court and Authoritie therof;

That every married Woman (living with her Husband in this Jurisdiction or other where absent from him with his consent or through his meer default, or inevitable providence, or in case of divorce where she is the innocent partie) that shal not before marriage be estated by way of joynture in some houses, lands, tenements or other hereditaments for term of her life, shall immediately after the death of her Husband have right and interest by way of dower, in, and to one third part of all such houses, lands, tenemẽts, rents and hereditaments as her said Husband was seized of, to his own use, either in possession, reversion or remainder in any estate of inheritance (or franc-tenement not then determined) at any time during the marriage to have and injoy for term of her natural life according to the estate of such Husband free, and freely discharged of and from all titles, debts, rents, charges, judgements, executions and other incumbrances whatsoever had, made, or suffered by her said Husband during the said marriage between them; or by any other person claiming by, from, or under him otherwise then by any act or consent of such Wife, as the laws of this Court shall ratefie and allow: and if the Heir of the Husband or other person interrested, shall not within one month after lawfull demand made, assigne and set out to such widow, her just third part with conveniencie or to her satisfaction according to the intent of this Law, then upõ a writt of dower in the court of that Shire where the said houses, lands, 
tenements or other hereditaments shall lye; or in the court of Assistants (if the same lye in several Shires) her dower or third part shal be assigned her to be set forth in severall by mets and bounds, by such persons as the same Court shall appoint for that purpose, with all costs and damages susteined. Provided alwayes that this Law shall not extend to any houses lands, tenements or other hereditaments solde or conveyed away, by any husband bona fide for valuable consideration, before the last of the ninth month now last past. And it is farther inacted that everie such Wife as is before expressed immediatly after the death of her Husband, shal have interest in, and unto one third part of all such monie, goods and chattels, real and personal of what kinde foever as her Husband shall dye possessed of (so much as shall be sufficient for the discharge of his Funerall and just debts being first deducted) to be allowed and set out to her as is heer before appointed for her Dowrie. Provided alwayes that every such widow so endowed as aforesaid shall not commit or suffer any strip or wast, but shal maintain all such houses, fences and inclosures as shall be assigned to her for her Dowrie, and shall leave the same in good and sufficient repairations in all points. [1647] ${ }^{27}$

The enactment was included in the edition of the Laws and Liberties of 1648 under the title "Dowries."

The 1641 enactment continued in force after the 1647 Dower Act, and the courts interpreted it to mean that the widow was to have, in addition to dower, whatever might be necessary for her support. ${ }^{28} \mathrm{~A}$ widow might presumably avail herself of the provisions of the Dower Act whether her husband died testate or intestate. In the event that he left a will which did not make adequate provision for her, she might complain to the General Court under the 1641 law and claim additional property. If the husband died intestate, she was entitled, by virtue of a law of 1649, to such part of his personal estate as the county court thought just and equal. ${ }^{28}$ In the 1660 edition of the Massachusetts laws, the word "personall" was omitted. ${ }^{30}$ The foregoing continued in force with but slight changes until 1692.31

Although the acts of 1641 and 1649 make certain provisions for the widow, we are not presently concerned with them, since they do not relate to dower. However, the principal provisions of the 1647

27. Laws and Liberties of Mass. 17-18 (1929).

28. 1 Probate Records of Essex County, Mass. 50, 67, 91, 106 (1916).

29. 2 Records of MAss. 281 (1853) ; 3 id. at 170.

30. Mass. Cor. Laws $1660-1672$ at 201 , c. 3 (1889).

31. 1 Acts and Resolves of the Province of Mass. Bay 48 (1869). 
act must be carefully noted: (1) the benefits of the act extended to every woman in the colony who was either married and living with her husband, or married and not living with him as a result of his consent or inevitable providence, or divorced and she was the innocent party; (2) the rights conferred by the act accrued upon marriage; ${ }^{32}$ (3) the widow's interest was an estate for her life, after the death of her husband, in one-third of all the realty of which her husband had been seised, in an estate of inheritance, ${ }^{33}$ at any time during the marriage; (4) although the estate did not come into her possession until her husband was dead, she could not be deprived of her inchoate right during the marriage by any act of her husband, or by any one claiming under him, unless she consented thereto; (5) her interest might be barred only by a jointure before marriage, by desertion on her part, or by divorce when she was the guilty party; (6) her estate was free from the claims of the husband's creditors; ( 7 ) upon her husband's death, her estate was to be assigned to her by her husband's heir or other person interested; (8) if the lands were not assigned to her within a month after her demand, she was entitled to a writ of dower to enforce her rights. The provision for giving the widow one-third of the husband's personal property outright, in addition to one-third of the realty for life, was dropped in $1649 . .^{34}$

In the absence of relevant information it is not possible to state with any certainty the immediate source of the 1647 act. Possibly the basic principle was borrowed from Plymouth Colony, where after 1636 a widow received one-third of her husband's lands for life and onethird of his personal property absolutely. ${ }^{35}$ Several achievements of Plymouth in the legal field appear to have been borrowed by Massachusetts Bay, for instance, the principle of partible inheritance, ${ }^{\mathbf{3 6}}$ the requirement of recording deeds, ${ }^{37}$ the device of codification. ${ }^{38}$ However, the Plymouth provision is by no means so detailed as that in

32. In the case of those already married in 1647 , the rights accrued at once and were apparently retroactive except as to conveyances made by the husband to bona fide purchasers for value prior to September $30,1647$.

33. That is, an estate in fee simple or fee tail. See note 13 supra.

34. 3 Reconds of Mass. 169-170 (1854): "Forasmuch as the printed lawe concerning dowries, upond second viewe and examinacion, appeares not so convenient as was formerly conceaved, in euery particuler thereof, itt is therefore hereby ordered, that the clawse towards the latter end of that order, that gives a wife a third parte of hir husbands mony, goods, and chattells, reall and personall, after hir husbands decease, shall henceforth be repealed and become voyd, and the rest of the said order to be, and remayne in full force and virtue."

35. The Compact with the Charter and Laws of the Colony of New PlymouTH 43 (Brigham's ed. 1836): "If the husband die the wife shall have a third part of his lands during her life and a $3 \mathrm{~d}$ of his goods to be at her owne disposeinge."

36. Haskins, Partible Inheritance, supra note 8, at 1281.

37. Haskins, Recording System, supra note 8, at 285 n. 19.

38. Goebel, supra note 7, at $418-419$ n. 7 . 
the Massachusetts act, and it apparently applied to property owned by the husband at his death and not to all property of which he had been seised during coverture. Whatever its immediate inspiration, the Massachusetts act seems clearly to have been modeled upon the rules of common law dower. No detailed comparison is required in the face of the striking similarities of the English and the Massachusetts laws.

A word must be said about dower by local custom in England. The right of a widow to share in her deceased husband's real property was universally acknowledged in English manorial law as well as by the common law courts. That right, known as freebench, varied in extent from place to place and might consist of one-fourth, one-third, one-half or the whole of her husband's realty. ${ }^{39}$ With such customs the Massachusetts colonists were very likely familiar, for many of them had been recruited from the class of artisans and small farmers, whose knowledge of manorial customs was more extensive than their acquaintance with the common law of the king's courts. It should be noted, however, that freebench was the widow's right to a share of the realty of which her husband had died seised and hence in the nature of a right of succession, a survival perhaps from an age when a wife may have been her husband's heir. ${ }^{40}$ At common law, the widow's right to one-third of the realty attached, as in Massachusetts, to all the lands of which her husband had been seised during coverture. Her right was one which accrued by virtue of the marital relationship and was one of which she could not be deprived by act of the husband; therefore it was not a right of succession. Freebench might entitle a widow to varying shares in her husband's estate, whereas in Massachusetts her rights attached to only one-third as at common law. In other words, the basic principles as well as the secondary characteristics of the Massachusetts law of dower are those of the English common law. It may not be without significance that it was in 1647 that the Massachusetts General Court voted to purchase several English law books, including a copy of Coke on Littleton. ${ }^{41}$

When we turn to the problem of how the Dower Act was administered by the courts, our conclusions must be less definite. It is not

39. 2 Watkins, A Treatise on Copyeolds $87-89$ (1799). Freebench should be clearly distinguished from dower by special custom under which a widow might take a life interest in one-half, instead of one-third, of the lands of which her husband had been seised during coverture. See Co. LITT. $* 33 \mathrm{~b}, * 111 \mathrm{a}$; Baker v. Berisford, 1 Keble 509, 83 Eng. Rep. 1081 (K. B. 1663).

40. Cf. Gomme, Widozehood in Manorial Law, 2 Archazological Rev. 184 (1888). In some customals the wife is explicitly referred to as her husband's heir: SHILLIBEER, Ancient Customs of the Manor of Taunton Deane 42 (1821); Imber, The Case and Customs of the Manor of Merdon 47 (1707); cf. Martin v. Wentworth, Noy 1, 74 Eng. Rep. 974 (Q. B. 1596). At common law a woman was never her husband's heir except in the rare instance where she happened to be related to him by blood and there was none nearer in degree than herself.

41. 2 RECORDS OF MASS. 212 (1853). 
possible to determine how closely the courts observed the provisions of the act without detailed examination of the original court records. Many of the published records have been edited from the point of view of the antiquarian or the genealogist rather than for the purpose of exhibiting the law in action, ${ }^{42}$ with the result that for present purposes they are often nearly useless. The reverse is true of the printed records of the Suffolk County Court, which provide a clearer picture of the law of dower in operation.

Several cases in the Suffolk records are concerned with claims for dower made by a widow against her husband's heir or grantee and show the courts disposing of the claims in accordance with the provisions of the 1647 act. $^{43}$ Other cases reveal that in the settlement of widows' claims the courts did not strictly adhere to the provisions of the Dower Act. It should here be noted that unlike contemporary England, where the administration of decedents' estates was in the hands of the ecclesiastical courts, probate jurisdiction in Massachusetts Bay belonged to the county courts. ${ }^{44}$ Although dower rights were theoretically independent of other claims against a deceased's estate, whether those claims arose under a will or under the intestacy laws, the courts frequently concerned themselves with dower in the settlement of a decedent's estate. Hence the estate cases provide further evidence of the actual administration of the Dower Act by the courts. In many cases the distributions ordered by the courts indicate that they did not give literal effect to the wording of the act. Thus a widow sometimes received a portion of her husband's estate (either land or personalty) outright instead of for life, "in Lieu of her dowry." 45 In one case the court gave the widow all the deceased's land, including the house, for her life. ${ }^{48}$ In another case the widow received one-half of her husband's houses and lands in fee simple and the other half for her life, ignoring the claim of the deceased's brother, who would have been the heir at common law. ${ }^{47}$ In three cases, when

42. This statement is particularly true of the Essex Probate Records.

43. Estate of Ellice, 2 SUFFolK CouNTY RECORDS 595 (1675); Vicars v. Joyliffe, id. at 755 (1676) ; Burnell v. Burnell, id. at 1096 (1679). Cf. Estate of Gross (1655) 3 RECORDS OF THE COURTS OF Assistants 1660/61 at 90 (1928); 3 Records of Mass. 1655 at 385 (1853).

44. See Haskins, Partible Inheritance, supra note 8 , at 1284.

45. Estate of Walker, 2 Sufrolk CounTY RECORDS 869 (1677). In this case the estate amounted to $£ 950$, of which the widow received $£ 490$ and the only child $£ 460$. In Estate of Ward, $2 i d$. at 1069 , the value of the estate was $f 413$, of which the widow was given \pm 113 outright in lieu of her dower. See also Estate of Shrimpton, 1 id. at 438 (1674) ; Estate of Pratt, 2 id. at 716 (1676) ; Estate of Davenport, 2 id. at 1105 (1679).

46. Estate of Tibbot (1650) 1 Records and Files of the Quarterly Courts of Essex County, MAss. 247 (1911).

47. Patten v. Dyer, 1 Sufrolk County Records 373 (1673/1674); Patten v. Winsley, id. at 377. This case is discussed in detail in Chafee, Professor Beale's Ancestor in HaRvard Legal Essays 39 (1934). 
the husband devised to his widow as large a share of his lands as she would have received by way of dower, she seems not to have been given her dower, ${ }^{48}$ although in England at that time she would have been entitled to dower also unless the devise was expressly stated to be in lieu of dower. ${ }^{49}$ Despite the provision of the Dower Act that the widow's interest should be free from the claims of the husband's creditors, ${ }^{50}$ there are suggestions that creditors may sometimes have been given priority, provided the remainder of the estate was sufficient for the widow's needs. ${ }^{51}$ In one case, the shares of the distributees of the estate, including the widow, were abated proportionately for the payment of creditors. ${ }^{52}$

Some distributions which disregarded the provisions of the Dower Act may have been the result of compromises between the widow and the other distributees of the estate, in which for the sake of simplicity of settlement or for other reasons the widow renounced her dower rights and was given a sum of money outright. Other cases seem to reflect a concern on the part of the courts for achieving fair results in particular cases. ${ }^{53}$ Authority for modifying the words of the 1647 act might have been found in the 1641 act which allowed the General Court to relieve a widow who had been left an insufficient portion by her husband ${ }^{54}$ and would presumably enable the county court to give a widow more than her thirds for life. ${ }^{55}$ At least once the 1649 act, which gave the county court power to assign to the widow such part of her husband's estate "as they shall conceive iust and equall," 56 was interpreted as applying to realty as well as personalty. ${ }^{57}$ Such an

48. Records and Files of the Quarterly Courts of Essex County, Mass. $127,168,239$ (1911). The entries in these records are not always complete, so that any statements based upon them may be open to question.

49. Co. LITT. *36 b; 1 WOERNER, ADMINISTRATIONS *266 (1899).

50. "Freely discharged of and from all titles, debts, rents charges, judgements, executions and other incumbrances whatsoever had, made, or suffered by her said Husband during the said marriage between them." LAwS AND LIBERTIES OF MASS. 17 (1929).

51. Estate of Walker, 2 Suffolk County Records 869 (1677),

52. Estate of Ward, id. at 1069 (1679).

53. For further discussion of that concern on the part of the courts, see Haskins, Partible Inheritance, sipra note 8, at $1293,1296$.

54. Mass. Cor. Laws $1660-1672$ at 51 , c. 79 (1889).

55. This argument does not seem ever to have been made.

56. 2 RECoRds of MASS. 281 (1853); 3 id. at 170; MAss. Col. Laws 1660-1672 201, c. 3 (1889).

57. Patten v. Dyer, 1 Suffolk County Records 373 (1673/1674); 1 Records of THE Assistants (1673/1674) 4 (1928). The original enactment in 1649 read "such a part of his personall estate as they shall conceive iust and equall." 2 Records of MAss. 281 (1853) ; 3 id. at 170 . The word "personal1" was omitted in the 1660 edition of the Laws. MASS. CoL. LAws 1660-1672 at 201, c. 3 (1889).

It may be pertinent to note that after the clause giving the widow a third part of her husband's personalty was stricken from the Dower Act in 1649 (see note 34 supra), the question arose whether the widow's one-third interest attached only to realty, or to realty and personalty. It was resolved in the Court of Assistants that "by A third part for the wife to be ment a third part of the whole." 3 RECORDS OF THE Assistants 91 (1928). 
interpretation did no violence to prevailing theories in Massachusetts, where in the administration of intestate estates the realty and personalty were valued together (contrary to the common law of England) and administered as one indiscriminate mass. ${ }^{58}$

It thus appears that although the Massachusetts Dower Act was based upon the rules of common law dower in England, it was interpreted by the courts in a manner which was in many instances at variance with the common law rules. With the legality of interpretations which were "contrary to the law of England" we are not here concerned. We are concerned with the various influences which shaped the early law of Massachusetts. It has been suggested elsewhere that the transplantation of customary law and local institutions was the basic fact in the colonial law of the seventeenth century, and considerable evidence has been advanced in support of the position that the law which the settlers brought with them was a curious mixture of religious ideas and of half-remembered customs from other lands. ${ }^{59}$ The present examination of the Massachusetts law of dower points to another element in stressing the influence of the English common law and tends to confirm Professor Plucknett's statement that as early as 1648 "there had been a voluntary reception of a good deal of common law, freely modified to meet local conditions." 60 Nevertheless, although common law influences can be found in the substantive and procedural law of that century, it must be remembered that there were few professional lawyers in the colony and few 'English treatises and law reports. The answer to the question of the relative contributions of customary, common and foreign law must await a detailed exposition of the "state of the law" in colonial Massachusetts. It may well prove true, as Professor Chafee has suggested, that the common law was present in some form at the start and that it "underwent a continuous reception as the growth of law libraries and serious legal students brought more and more case law and detailed doctrines from England." 61

Professor Max Radin has observed pertinently that "the common law in the period between 1660 and 1776 certainly made great strides toward the domination of the law of America. But it never quite achieved it. Throughout the Colonial period it remained a subsidiary, supplementary law, . . . regarded some times with veneration and

58. See Haskins, Partible Inheritance, supra note 8, at 1289. In England, at common law, the real estate passed directly to the heir and did not come within the jurisdiction of the probate court.

59. Goebel, supra note 7; Haskins, supra note 8.

60. Plucknett, Book Review, 3 NEw England Quarterly 157 (1930).

61. Chafee, Book Review, 57 Harv. L. Rev. 399, 414 (1944). 
at others with suspicion and hostility." ${ }^{2}$ In seventeenth-century Massachusetts the influence of the common law seems to have been less significant than other elements. Because in the beginning the growth of the law was not overly hampered by traditional doctrines and rules it was possible for an indigenous law to develop in response to the social and economic conditions of the new American civilization.

62. Radin, The Rivalry of Common-Lawe and Civil Laze Ideas in the American Colonies in 2 Law, A Century of Progress, 404, 427 (1937). 